\title{
INVESTIGATION OF FLEXURAL LOAD CARRYING PERFORMANCE OF RC BEAMS REPAIRED WITH ULTRA HIGH PERFORMANCE FIBER REINFORCED CONCRETE
}

\author{
K. KAKUMA ${ }^{*}$ AND H. NISHI ${ }^{\dagger}$ \\ *Civil Engineering Research Institute for Cold Region, PWRI \\ Sapporo, Japan \\ e-mail: kakuma@ceri.go.jp \\ ${ }^{\dagger}$ Civil Engineering Research Institute for Cold Region, PWRI \\ Sapporo, Japan \\ e-mail: h-nishi@ceri.go.jp
}

Key words: UHPFRC, Flexural Load Carrying Performance, Repair

\begin{abstract}
This study conducted pull-out test of reinforcing bars embedded in UHPFRC, and flexural test of UHPFRC beams containing reinforcing bars (R-UHPFRC) and flexural test of UHPFRC-RC beams. In pull-out test and flexural test of R-UHPFRC, round bars are provided as well as deformed bars to investigate the influence of reinforcing bar type on the fundamental behavior of R-UHPFRC. From the results, bond strength between reinforcing bars and UHPFRC was affected by reinforcing bar type, and the influence of bond characteristics appeared in postpeak behavior under flexure. Flexural test of UHPFRC-RC beams showed that partial replacement of concrete section with UHPFRC improved load carrying capacity independent on repair position and thickness. However, when tensile zone was repaired with thickness which exceeds cover thickness, high bond strength between deformed bars and UHPFRC induced catastrophic failure due to the rupture of reinforcing bars.
\end{abstract}

\section{INTRODUCTION}

Ultra high performance fiber reinforced concrete (UHPFRC) comes to be generally used in a construction of new structures, utilizing low permeability as well as high strength such as compressive strength of 150 to $200 \mathrm{~N} / \mathrm{mm}^{2}$ and tensile strength of more than $8 \mathrm{~N} / \mathrm{mm}^{2}$. Recently, materials which can be successively manufactured in-situ without heat curing and do not require special construction machines have been developed [1], so that such ambient curable type UHPFRC is highly expected to be applied to the rehabilitation of deteriorated concrete structures. Actually in Europe, it has been already applied to the reinforcement of bridge slabs and the surface coating of bridge wall handrails [2].

To investigate the fundamental behaviors of UHPFRC and RC structures repaired with UHPFRC, this study conducted three considerations: pull-out test of reinforcing bars embedded in UHPFRC, flexural test and finite element analysis of UHPFRC beams containing reinforcing bars (R-UHPFRC), and flexural test of UHPFRC-RC beams. In first and second considerations, not only deformed bars but also round bars were provided, because round bars have been often installed in concrete structures subjected to rehabilitation in Japan, and it is greatly important to evaluate the behavior of 
UHPFRC members using round bars. In third consideration, load carrying performance of UHPFRC-RC with various repair positions and thicknesses is examined.

\section{PULL-OUT TEST OF REINFORCING BARS EMBEDDED IN UHPFRC}

\subsection{Test procedure}

In pull-out test of reinforcing bars embedded in UHPFRC, reinforcing bar type is taken for a test variable as listed in Table 1. Three specimens are tested in each case.

Figure 1 shows the geometric properties of specimens. Specimens have the rectangular cross-section with $150 \mathrm{~mm}$ width and $150 \mathrm{~mm}$ height, and either a deformed bar (D13) or a round bar $(\phi 13)$ is installed in UHPFRC. The bonded zone is placed at the center of UHPFRC block with 200mm length, and bond is removed by using vinyl pipe except for bonded zone. The direction of UHPFRC placing is also shown in Figure 1. Mechanical properties of UHPFRC and reinforcing bars are listed in Table 2 and Table 3, respectively.

Figure 2 shows the outline of pull-out test of reinforcing bars. A tension bar is mechanically connected with a reinforcing bar and it is pulled by using a center-hole jack. Load is monotonically added under load control until the reinforcing bar fractures or top displacement of the tension bar reaches the maximum stroke of the jack. During test, load, top displacement of tension bar, bottom displacement of reinforcing bar, strain of reinforcing bar in unbonded zone and strain of tension bar are basically measured. For one of the three specimens in each case, strain of reinforcing bar is additionally measured in bonded zone.

\subsection{Test results}

For the results of pull-out test of reinforcing bars, the load-top displacement relation, the load-bottom displacement relation, the loadreinforcing bar strain in unbonded zone relation and the load-reinforcing bar strain in bonded zone relation are shown in Figure 3. In
Table 1: List of specimes for pull-out test of reinforcing bars

\begin{tabular}{ccc}
\hline Case & $\begin{array}{c}\text { Reinforcing } \\
\text { bar type }\end{array}$ & $\begin{array}{c}\text { Bond length } \\
(\mathrm{mm})\end{array}$ \\
\cline { 1 - 2 } D200 & D13(SD295A) & 200 \\
\cline { 1 - 2 }$\phi 200$ & $\phi 13($ SR235) & \\
\hline
\end{tabular}

Table 2: Compression test result of UHPFRC

\begin{tabular}{ccc}
\hline $\begin{array}{c}\text { Age } \\
\text { (days) }\end{array}$ & $\begin{array}{c}\text { Strength } \\
\left(\mathrm{N} / \mathrm{mm}^{2}\right)\end{array}$ & $\begin{array}{c}\text { Elastic modulus } \\
\left(\mathrm{kN} / \mathrm{mm}^{2}\right)\end{array}$ \\
\hline 28 & 156.9 & 34.0 \\
\hline
\end{tabular}

Table 3: Tension test result of reinforcing bars

\begin{tabular}{cccc}
\hline $\begin{array}{c}\text { Reinforcing } \\
\text { bar type }\end{array}$ & $\begin{array}{c}\text { Yield } \\
\text { strength } \\
\left(\mathrm{N} / \mathrm{mm}^{2}\right)\end{array}$ & $\begin{array}{c}\text { Tensile } \\
\text { strength } \\
\left(\mathrm{N} / \mathrm{mm}^{2}\right)\end{array}$ & $\begin{array}{c}\text { Elongation } \\
(\%)\end{array}$ \\
\hline $\begin{array}{c}\mathrm{D} 13 \\
(\mathrm{SD} 295 \mathrm{~A})\end{array}$ & 346.8 & 455.9 & 13.9 \\
\hline $\begin{array}{c}\phi 13 \\
(\mathrm{SR} 235)\end{array}$ & 316.5 & 453.4 & 29.2 \\
\hline
\end{tabular}

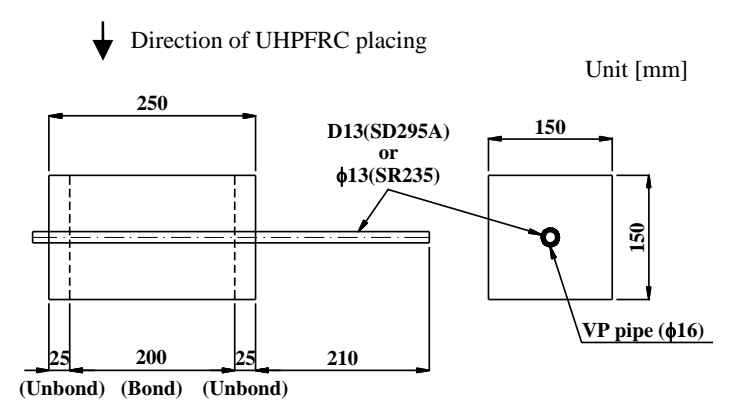

Figure 1: Dimension of specimen for pull-out test of reinforcing bars

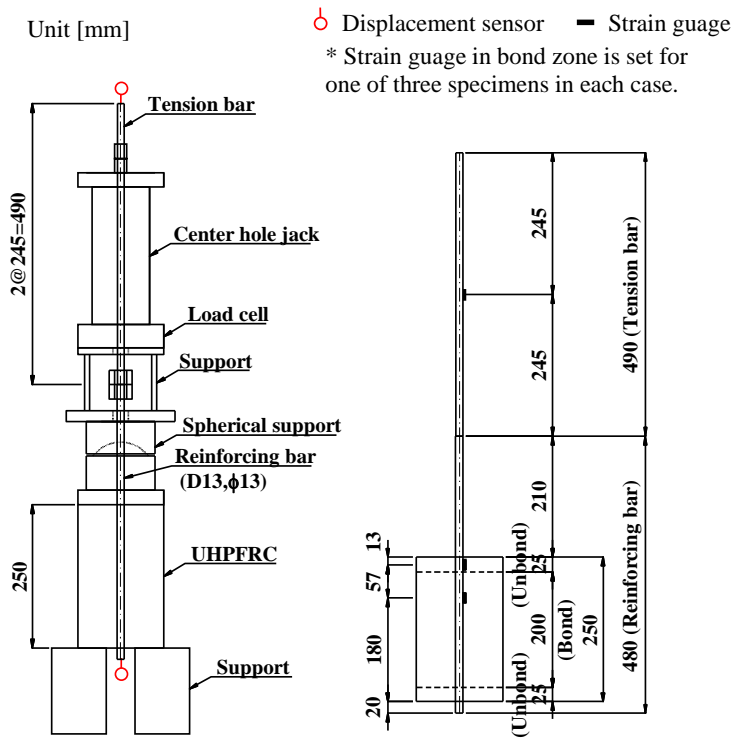

$\begin{array}{ll}\text { (a) Setup } & \text { (b) Strain measured position }\end{array}$

Figure 2: Outline of pull-out test of reinforcing bars 
$\multimap$ No.1 $\square$ No.2 $\square-$ No.3 $\longrightarrow$ Calculation $-\cdot-$ Yield strain

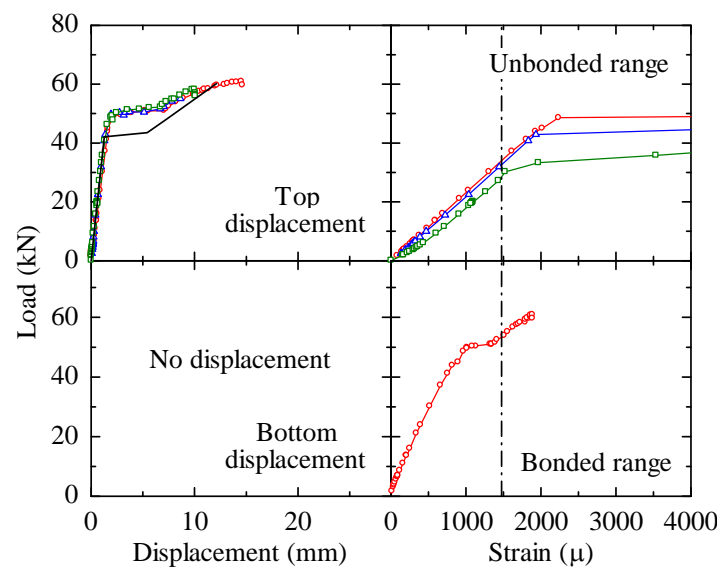

(a) D200

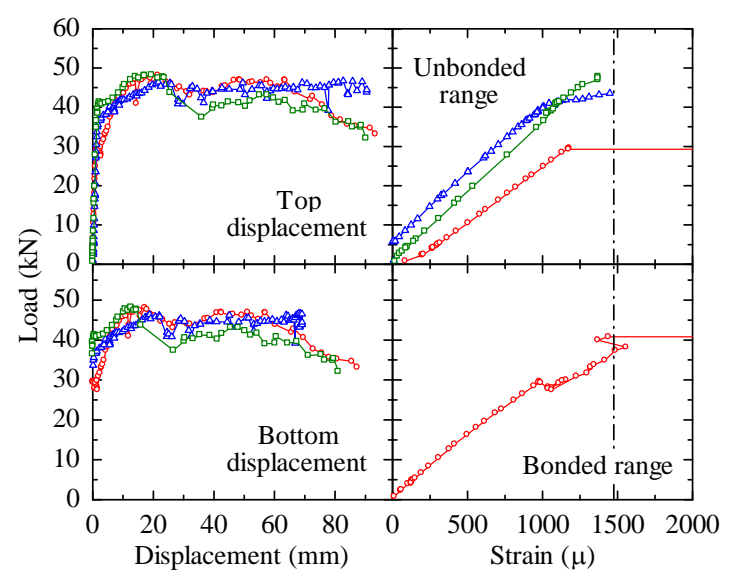

(b) $\phi 200$

Figure 3: Results of pull-out test of reinforcing bars

the load-top displacement relation, the relation calculated by using stress-strain relations of reinforcing bars and tension bar is shown together.

In Case-D200 using deformed bars, reinforcing bars fractured or the indication of reinforcing bar fracturing was seen after elastic-plastic behavior with yield plateau which is often observed in tension of common steels. Bottom of reinforcing bar never moved through the tension process, meaning the bond strength between deformed bars and UHPFRC was extremely high and top displacement was determined by the elongation of tension bar and reinforcing bar along unbonded zone. Here, the difference in load between test and calculation might be caused by the load loss at the joint part between reinforcing bar and tension bar.

In Case- $\phi 200$ using round bars, bottom displacement started to increase at the almost same time of the increase in top displacement when load reached 30 to $40 \mathrm{kN}$. From the evolution of reinforcing bar strain in bonded zone, it is shown that the initial linear slope of strain increase was kept just before the occurrence of bottom displacement. This intends that bond failure rapidly spread downward from the boundary between unbonded and bonded zones during the slight increase in load. After the occurrence of slip of reinforcing bar, slip-hardening behavior, in which load is increased or kept to be constant,
Table 4: List of specimens for flexural test of R-UHPFRC

\begin{tabular}{cc}
\hline Case & Reinforcing bar type \\
\hline UHPFRC & without reinforcing bars \\
\hline $\mathrm{R}_{\mathrm{d}}$-UHPFRC & $\mathrm{D} 13(\mathrm{SD} 295 \mathrm{~A})$ \\
\hline $\mathrm{R}_{\mathrm{r}}$-UHPFRC & $\phi 13(\mathrm{SR} 235)$ \\
\hline
\end{tabular}

was observed. From the pull-out test of short fibers embedded in fiber reinforced concrete, it has been reported that some types of fibers show slip-hardening behavior due to the abrasion of fiber surface during pull-out process [3-4]. There is a difference in fibers and reinforcing bars, but the same phenomenon might happen in this test.

\section{FLEXURAL TEST OF R-UHPFRC}

\subsection{Test procedure}

Table 4 lists the cases of flexural test. For R-UHPFRC two types of reinforcing bars, deformed bar and round bar, are provided. In each case, three specimens are tested.

Figure 4 shows the geometric properties of specimens. Specimens have the cross-section with $80 \mathrm{~mm}$ width and $90 \mathrm{~mm}$ height, and $1,000 \mathrm{~mm}$ length. At the end of beams, reinforcing bars are fixed to steel plates by welding. UHPFRC is placed at the same time of manufacturing pull-out test specimens.

Figure 5 shows the setup of flexural test. 


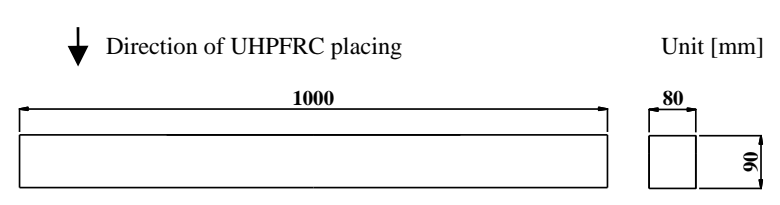

(a) UHPFRC

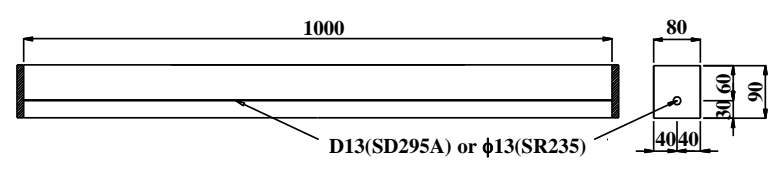

(b) $\mathrm{R}_{\mathrm{d}}$-UHPFRC, $\mathrm{R}_{\mathrm{r}}$-UHPFRC

Figure 4: Dimension of specimens for flexural test of R-UHPFRC

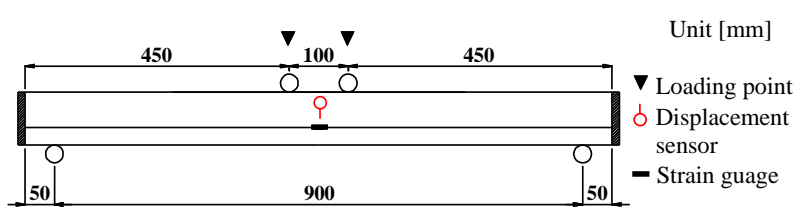

Figure 5: Outline of flexural test of R-UHPFRC

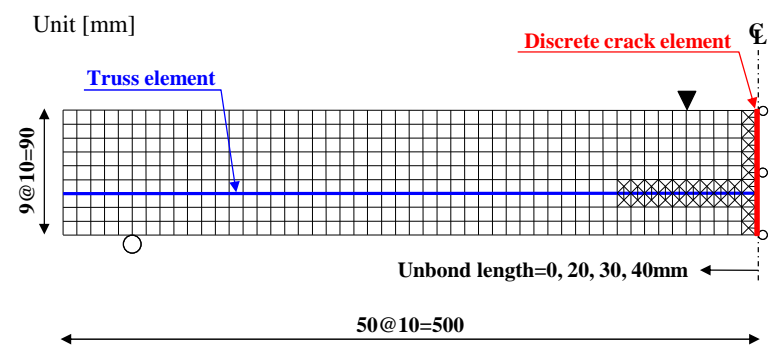

Figure 6: Finite element mesh

Test is conducted by four-point flexure with uniform flexural span of $100 \mathrm{~mm}$ and shear span of $400 \mathrm{~mm}$. Loading is controlled by load increment before the initiation of flexural crack and done by displacement increment after the flexural cracking. During the test, load, midspan deflection and strain of reinforcing bar are measured.

\subsection{Finite element analysis}

Finite element analysis taking account of bond characteristics is conducted in order to examine the influence of reinforcing bar type on flexural behavior of R-UHPFRC.

Figure 6 shows the mesh of analytical model. By taking advantage of symmetry with respect to the centerline, half of a model is analyzed. UHPFRC and reinforcing bars are modeled by using plane stress elements and truss elements, respectively. Because the post-

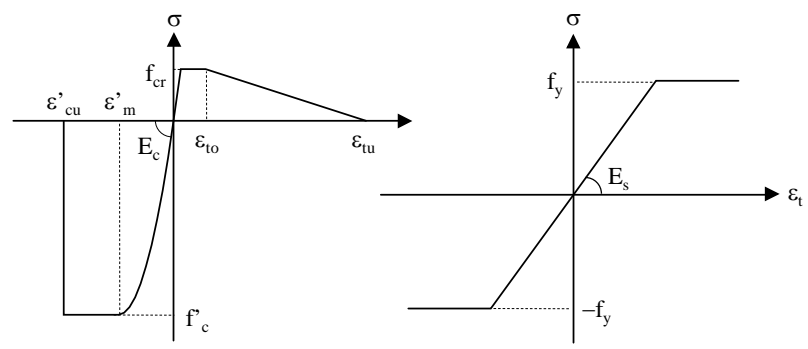

$\begin{array}{ll}\text { (a) UHPFRC } & \text { (b) reinforcing bars }\end{array}$

Figure 7: Stress-strain relation

peak behavior of UHPFRC under flexure is dominated by the opening of localized crack, discrete crack elements are installed at symmetric plane to present localized cracking process. In addition, bond-slip elements are set between UHPFRC elements and reinforcing bar elements to consider bond characteristics. Here, the difference in bond characteristics are introduced by unbonded length, and the length is set to be $20,40,60,80 \mathrm{~mm}$ of beam center.

Elastic-plastic model is used for both UHPFRC and reinforcing bars with the stressstrain relations as shown in Figure 7. For discrete crack elements, bi-linear tractioncrack opening displacement relation with softening behavior and linear relation with well large stiffness are defined in normal and shear directions, respectively. For bond-slip elements, considerably small and large shear stiffness are set to unbonded and bonded zone.

\subsection{Test results}

Figure 8(a) shows the relation between load and midspan deflection, and Figure 8(b) shows the relation between load and reinforcing bar strain in Case-Rr-UHPFRC. Also, crosssectional analysis result is plotted together with test result. In the figures, broken lines mean the maximum load calculated by using a cross-section considering nonlinear tensile behavior of UHPFRC, $P_{\max }$, and dashed-dotted lines mean the yield load calculated by using a cross-section neglecting tensile stress of UHPFRC, $\mathrm{P}_{\mathrm{y} 0}$.

In Case-UHPFRC without reinforcing bars, gradual decrease in load was brought by the opening of localized crack within uniform flexural span after deflection hardening 


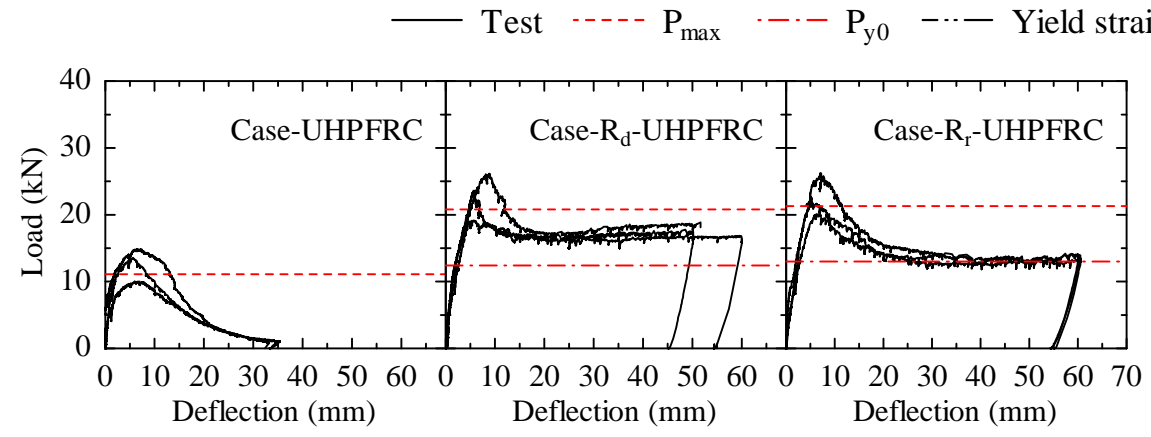

(a) Relation between load and midspan deflection

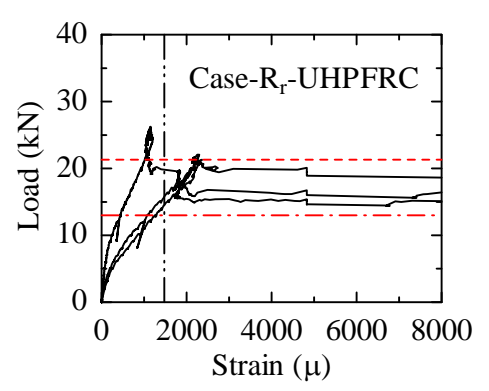

(b) Relation between load and strain

Figure 8: Results of flexural test of UHPFRC and R-UHPFRC

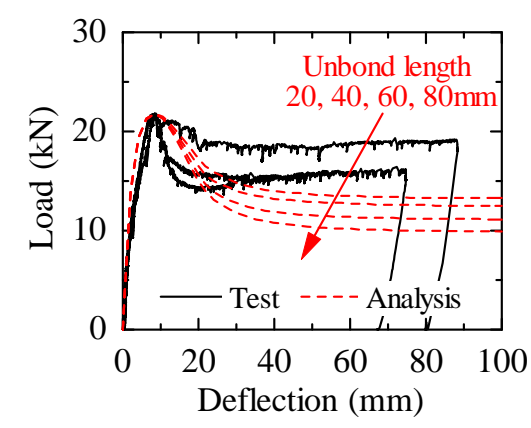

(a) $\mathrm{R}_{\mathrm{d}}$-UHPFRC

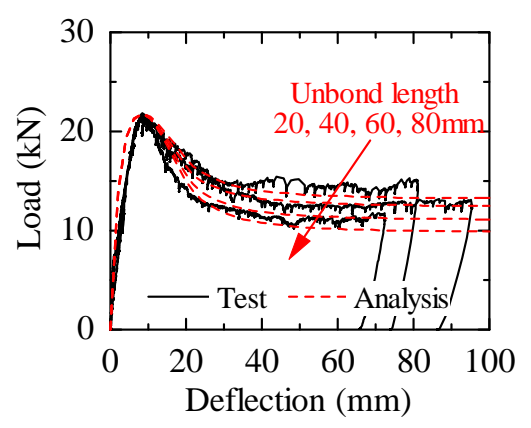

(b) $\mathrm{R}_{\mathrm{r}}$-UHPFRC

Figure 9: Comparison between test and analysis

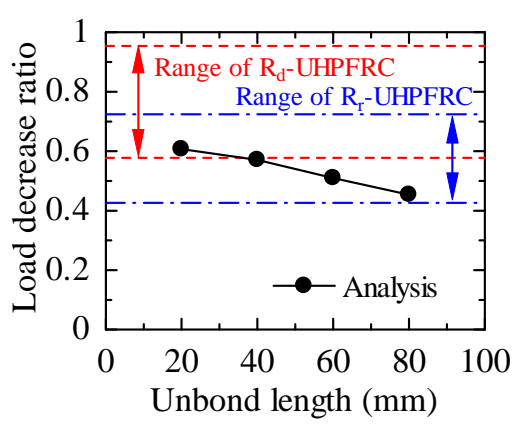

Figure 10: Relation between load decrease ratio and unbond length behavior. The range of maximum flexural stress was 18.6 to $27.6 \mathrm{~N} / \mathrm{mm}^{2}$.

In the cases of $R_{d}$-UHPFRC and $R_{r}-$ UHPFRC, load decrease due to localized crack opening was seen after yield of reinforcing bar. Focusing on pre-peak behavior, the difference in behavior due to installed reinforcing bar type was not obvious, and peak load and midspan deflection were almost within the same range in all specimens. On the other hand, post-peak behavior was influenced by reinforcing bar type: load became constant at the level that exceeds $P_{y 0}$ in $R_{d}-U H P F R C$, but at the level of $\mathrm{P}_{\mathrm{y} 0}$ in $\mathrm{R}_{\mathrm{r}}$-UHPFRC. From the evolution of reinforcing bar strain in $\mathrm{Rr}$ UHPFRC shown in Figure 8(b), reinforcing bar strains already exceeded yield level in load decrease process, meaning tensile load more than $40 \mathrm{kN}$ might act on reinforcing bars. Because bond failure between round bars and UHPFRC occurred when load reached 30 to $40 \mathrm{kN}$ in pull-out test, it was suggested that enough tensile load acted on reinforcing bars to cause bond failure in $\mathrm{Rr}$-UHPFRC.

Figure 9 compares the flexural behaviors obtained from test and FE analysis. Here, loaddeflection curves are normalized by using peak load and the deflection. In the analytical results, larger unbonded length brought steeper load decrease after peak, while it does not affect the pre-peak behavior. The ratio between peak load and load when deflection equals to $50 \mathrm{~mm}$ is shown in Figure 10 . The analytical load reduction ratio tends to become large with the increase in unbonded length. Also, about the ratio obtained from test, $\mathrm{Rr}^{-}$ UHPFRC generally shows the larger load decrease than $R_{d}$-UHPFRC. From the above, post-peak behavior of R-UHPFRC depends on bond characteristics of reinforcing bars, and it is necessary to taking into account of bond characteristics properly to evaluate the postpeak behavior of R-UHPFRC. 


\section{FLEXURAL TEST OF RC BEAMS WITH UHPFRC RETROFITTING}

\subsection{Test procedure}

Flexural test of RC beams partially replaced by using UHPFRC with various repair positions and thicknesses is conducted. The test cases are shown in Table 5. Here, repair with $20 \mathrm{~mm}$ thickness corresponds to thin repair less than cover thickness, and that with $60 \mathrm{~mm}$ thickness does to repair assuming well integration between UHPFRC and existing concrete by UHPFRC casting so that reinforcing bars are included in UHPFRC layer.

Figure 11 and Table 6 show the properties

Table 5: List of specimes for flexural test of UHPFRC-RC

\begin{tabular}{|c|c|c|}
\hline Case & $\begin{array}{c}\text { Repair } \\
\text { position }\end{array}$ & $\begin{array}{c}\text { Repair } \\
\text { thickness } \\
(\mathrm{mm})\end{array}$ \\
\hline B-0 & none & - \\
\hline BU-20 & \multirow{3}{*}{ Upper } & 20 \\
\hline BU-40 & & 40 \\
\hline BU-60 & & 60 \\
\hline BL-20 & \multirow{3}{*}{ Lower } & 20 \\
\hline BL-40 & & 40 \\
\hline BL-60 & & 60 \\
\hline
\end{tabular}

of control beam (B-0) without UHPFRC repair. Specimens have the cross-section with $250 \mathrm{~mm}$ width and $400 \mathrm{~mm}$ height. The length and span are $3,000 \mathrm{~mm}$ and $2,800 \mathrm{~mm}$, respectively. The shear span ratio is 2.8 and stirrups are installed at $200 \mathrm{~mm}$ intervals. At the joint part between existing concrete and UHPFRC, aggregate expression by the combination of retarder splaying and washing out concrete creates enough roughness for the integration of concrete and UHPFRC. Mechanical properties of concrete, UHPFRC and reinforcing bars are listed in Table 7 and Table 8.

Test is conducted by four-point flexure with uniform flexural span of $800 \mathrm{~mm}$ and shear span of $1,000 \mathrm{~mm}$. Loading is continued to the

Table 7: Compression test result of Concrete and UHPFRC

\begin{tabular}{cccc}
\hline Material & $\begin{array}{c}\text { Age } \\
\text { (day) }\end{array}$ & $\begin{array}{c}\text { Strength } \\
\left(\mathrm{N} / \mathrm{mm}^{2}\right)\end{array}$ & $\begin{array}{c}\text { Elastic } \\
\text { modulus } \\
\left(\mathrm{kN} / \mathrm{mm}^{2}\right)\end{array}$ \\
\hline Concrete & 186 & 29.7 & 24.3 \\
\hline UHPFRC & 42 & 156.3 & 34.6 \\
\hline
\end{tabular}

Table 8: Tension test result of reinforcing bars

\begin{tabular}{cccc}
\hline $\begin{array}{c}\text { Reinforcing } \\
\text { bar type }\end{array}$ & $\begin{array}{c}\text { Yield } \\
\text { strength } \\
\left(\mathrm{N} / \mathrm{mm}^{2}\right)\end{array}$ & $\begin{array}{c}\text { Tensile } \\
\text { strength } \\
\left(\mathrm{N} / \mathrm{mm}^{2}\right)\end{array}$ & $\begin{array}{c}\text { Elongation } \\
(\%)\end{array}$ \\
\hline $\begin{array}{c}\mathrm{D} 13 \\
(\mathrm{SD} 345)\end{array}$ & 386 & 546 & 24 \\
\hline $\begin{array}{c}\mathrm{D} 10 \\
(\mathrm{SD} 345)\end{array}$ & 376 & 519 & 28 \\
\hline
\end{tabular}

Table 6: Properties of B-0 specimen

\begin{tabular}{cccccc}
\hline $\begin{array}{c}\text { Shear span } \\
\text { ratio }\end{array}$ & $\begin{array}{c}\text { Reinforcing } \\
\text { bar type }\end{array}$ & $\begin{array}{c}\text { Ratio of tensile } \\
\text { reinforcement }\end{array}$ & $\begin{array}{c}\text { Ratio of shear } \\
\text { reinforcement }\end{array}$ & Shear capacity & $\begin{array}{c}\text { Flexural } \\
\text { capacity }\end{array}$ \\
\hline- & - & $\%$ & $\%$ & $\mathrm{kN}$ & $\mathrm{kN}$ \\
\hline 2.8 & SD345 & 0.50 & 0.28 & 252.4 & 92.6 \\
\hline
\end{tabular}

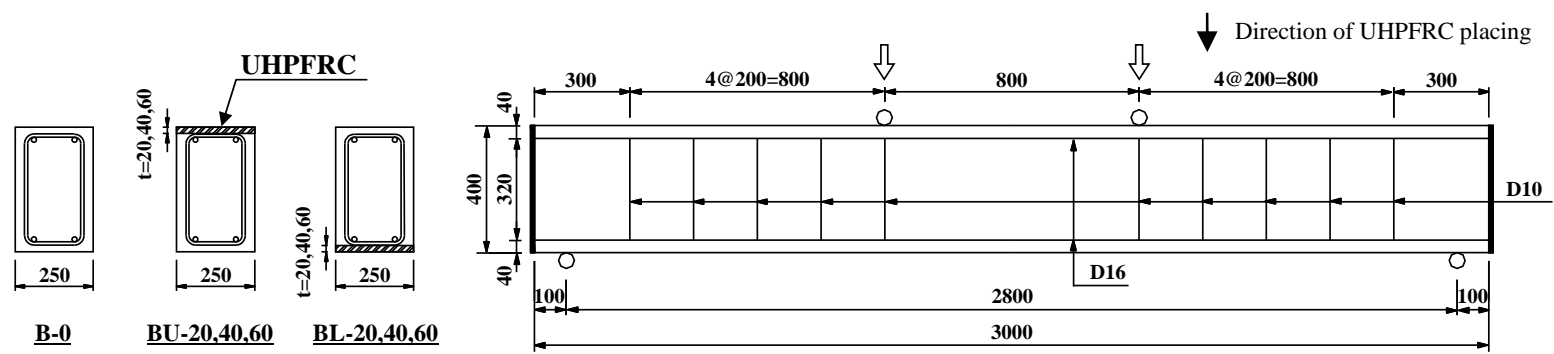

Figure 11: Dimension of specimens for flexural test of UHPFRC-RC 


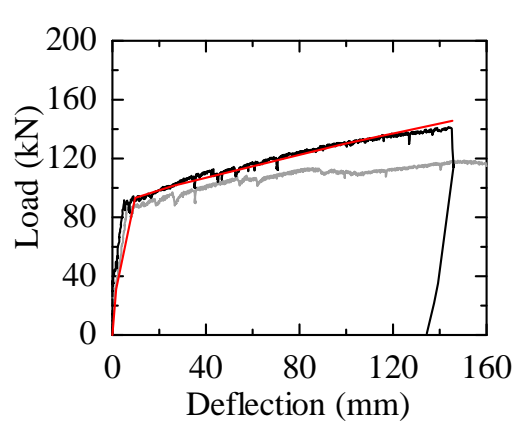

(a) BU-20

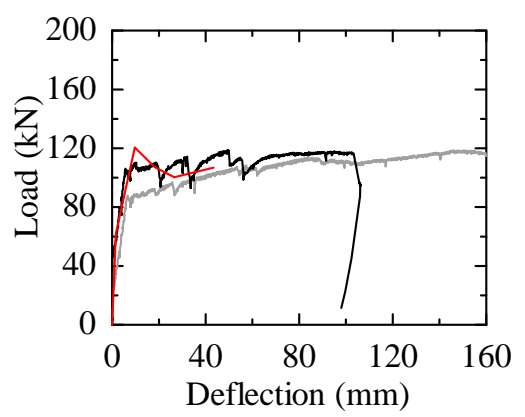

(d) BL-20

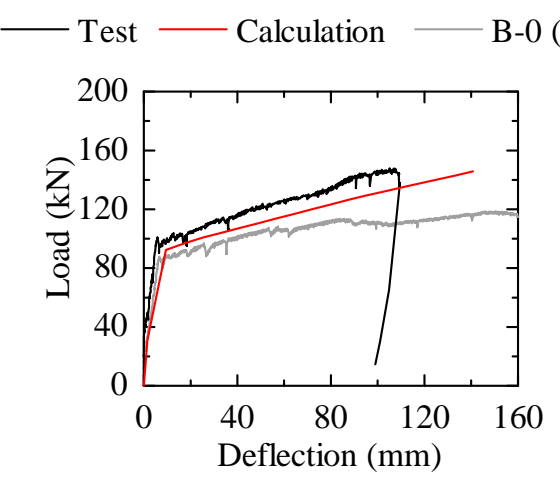

(b) BU-40

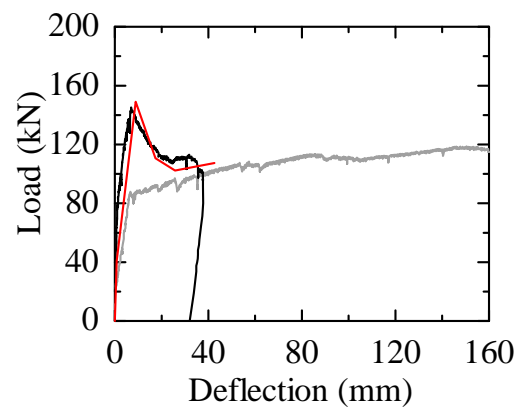

(e) BL-40

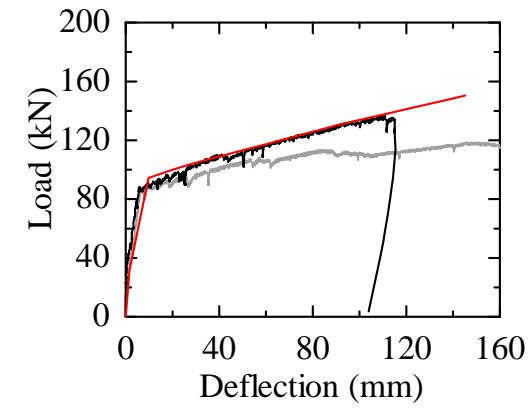

(c) BU-60

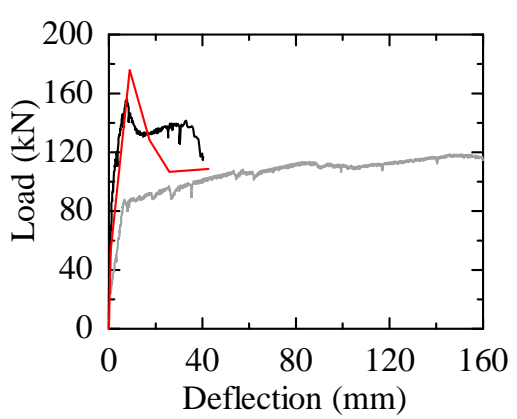

(f) BL-60

Figure 12: Results of flexural test of UHPFRC-RC

failure of specimens or the limitation of jack stroke under load control. During test, load and midspan deflection are measured.

\subsection{Test result}

In Figure 12, the load-midspan deflection curves obtained from specimens with UHPFRC repair are shown along with the test result of B-0 and the cross-sectional analysis results. Table 9 lists the maximum loads and failure modes obtained from both test and analysis. The relation between maximum load and repair thickness is shown in Figure 13. For un-fractured specimens (B-0 and BU-60), maximum loads obtained within the test are shown as reference in Table 9 and Figure 13. From Figure 12, load-deflection curves of upper repair series are basically similar to B-0, but the slope of load increase after the yield of reinforcing bars became larger. From the view point of maximum load, it was insensitive to the increase in repair thickness while the partial replacement of concrete with UHPFRC considerably contributed to the load increase. In lower repair series, maximum load increased due to tensile resistance of UHPFRC
Table 9: Maximum load and faiure modes

\begin{tabular}{ccccc}
\hline & \multicolumn{2}{c}{ Test } & \multicolumn{2}{c}{ Calculation } \\
\cline { 2 - 5 } Case & $\begin{array}{c}\text { Maximum } \\
\text { load } \\
(\mathrm{kN})\end{array}$ & $\begin{array}{c}\text { Failure } \\
\text { modes }\end{array}$ & $\begin{array}{c}\text { Maximum } \\
\text { load } \\
(\mathrm{kN})\end{array}$ & $\begin{array}{c}\text { Failure } \\
\text { modes }\end{array}$ \\
\hline B-0 & 113.5 & $\mathrm{CC}$ & 109.7 & $\mathrm{CC}$ \\
\hline BU-20 & 142.2 & $\mathrm{UC}$ & 145.6 & $\mathrm{R}$ \\
\hline BU-40 & 148.2 & $\mathrm{R}$ & 147.7 & $\mathrm{R}$ \\
\hline BU-60 & 137.0 & - & 150.4 & $\mathrm{R}$ \\
\hline BL-20 & 118.9 & $\mathrm{CC}$ & 120.5 & $\mathrm{CC}$ \\
\hline BL-40 & 145.3 & $\mathrm{R}$ & 149.1 & $\mathrm{CC}$ \\
\hline BL-60 & 156.3 & $\mathrm{R}$ & 175.9 & $\mathrm{CC}$ \\
\hline Failure modes CC: concrete crush \\
UC: UHPFRC crush \\
\multicolumn{5}{c}{ R: reinforcing bar fracture }
\end{tabular}

and it was proportional to the increase in repair thickness. After peak, load gradually decreased and tended to approximate B-0, suggesting tensile resistance of UHPFRC disappeared and flexural behavior was dominated by the behavior of reinforcing bars.

Crack patterns at the end of test are shown in Figure 14. Control beam (B-0) and upper 


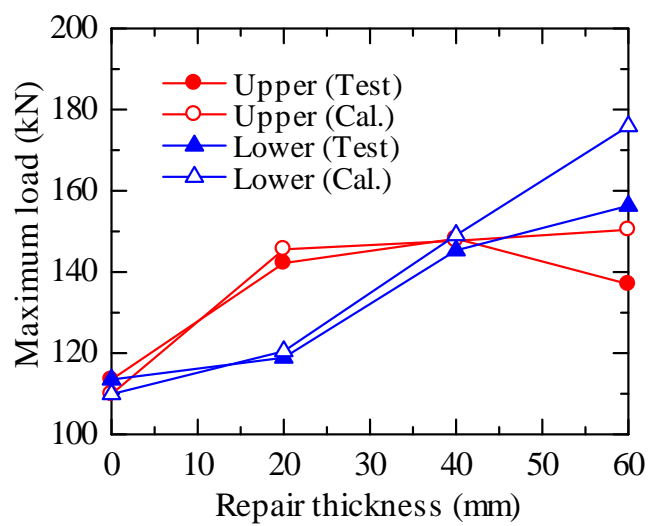

Figure 13: Relation between maximum load repair thickess

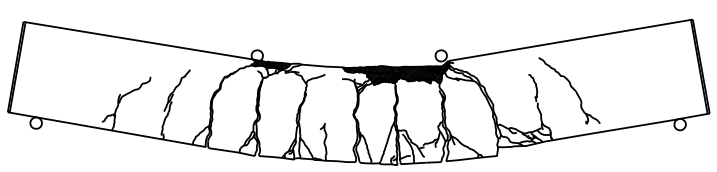

(a) B-0

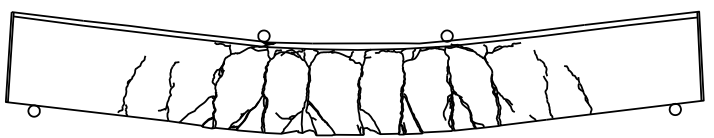

(b) BU-20

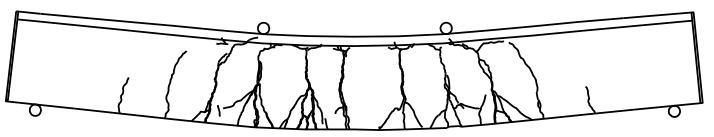

(c) BU-40

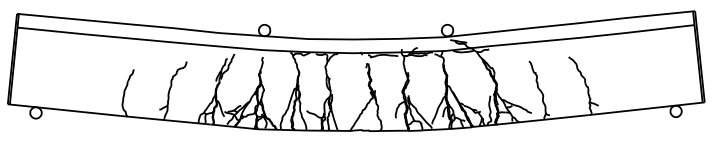

(d) BU-60

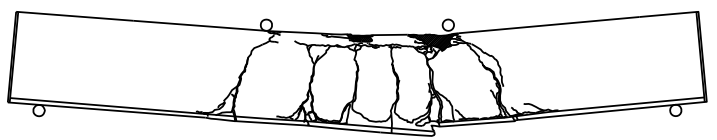

(e) BL-20

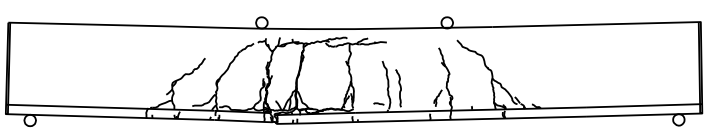

(f) BL-40

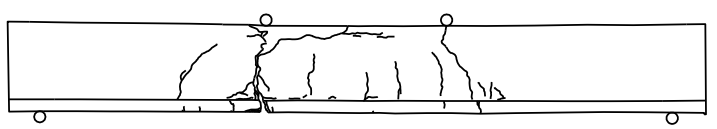

(g) BL-60

Figure 14: Crack patterns

repair series (BU-20, BU-40, BU-60) showed similar crack patterns: crack initiation range and intervals. However, a direct factor to cause final load decrease varied depending on repair thickness: thin repair caused compressive failure of upper concrete or UHPFRC and thick repair did reinforcing bar fractures. In lower repair series, crack initiation range became smaller than in upper repair series. In this series, flexural behavior depended on localized crack behavior, and crack distributed in smaller range than in upper repair series. In BL-40 and BL-60 in which reinforcing bars were installed in UHPFRC layer, failure modes shifted from flexural failure with compressive failure of upper concrete or UHPFRC to reinforcing bar fracture compared with B-0. As shown in pull-out test, deformed bars have extremely high bond strength with UHPFRC, and this brought the local elongation of reinforcing bars within crack plane and reinforcing bar fracture.

\section{CONCLUSIONS}

This study investigated the fundamental behaviors of UHPFRC and UHPFRC-RC composite structures based on pull-out test of reinforcing bars embedded in UHPFRC and flexural tests of R-UHPFRC beams and UHPFRC-RC beams. The findings are shown as below.

[1] The pull-out test using deformed bars showed the extremely high bond strength between deformed bars and UHPFRC brought reinforcing bar fracture under the condition with $200 \mathrm{~mm}$ of initial bond length. From the test using round bars, slip-hardening behavior in which load continues to increase under pull-out was observed.

[2] Flexural test and the analysis of RUHPFRC showed the influence of reinforcing bar type appeared in the postpeak behavior, and the smaller bond strength or longer unbonded length caused larger gradient and degree of load decrease.

[3] From the flexural test of UHPFRC-RC composite beams, flexural load carrying capacity was improved by partially replacing using UHPFRC in both cases of tension and compression repairs. However, 
the increase in UHPFRC thickness might make failure modes change to catastrophic modes.

\section{REFERENCES}

[1] Denarié, E. 2009. Recommendations for the Tailoring of UHPFRC Recipes for Rehabilitation. Deliverable ARCHES D06.

[2] Brühwiler, E. 2012. Rehabilitation and Strengthening of Concrete Structures using Ultra-High Performance Fiber Reinforced Concrete. Concrete Repair, Rehabilitation and Retrofitting III: 72-79.

[3] Redon, C., Li, Victor C., Wu, C., Hoshiro, H., Saito, T. and Ogawa, A. 2001. Measuring and Modifying Interface Properties of PVA Fibers in ECC Matrix. Journal of Materials in Civil Engineering 13(6): 399-406.

[4] Wille, K. and Naaman, A. E. 2010. Bond Stress-Slip Behavior of Steel Fibers Embedded in Ultra High Performance Concrete. Proceedings of 18th European Conference on Fracture Damage of Advanced Fiber-Reinforced CementBased Materials: 99-111. 